\title{
PENGARUH SUPPLEMENTASI PROBIOTIK DAN SELENIUM TERHADAP RESPON IMUN NLR (NEUTROPHIL LYMPHOCYTE COUNT RATIO), HAEMOGLOBIN DAN ALBUMIN PADA TIKUS WISTAR YANG DIINDUKSI MYCOBAKTERIUM TUBERCULOSIS
}

\author{
Yuliati Widiastuti $^{1 *}$, S.S Darmono², Muchlis Achsan Udji Sofro ${ }^{3}$ \\ ${ }^{1}$ STIKES Immanuel Bandung, J1. Raya Kopo No.161, Situsaeur, Bojongloa Kidul, Kota Bandung, Jawa Barat 40232 , \\ Telepon: (022) 5212326, email : yuliatiwidiastuti@gmail.com \\ ${ }^{2}$ Fakultas Kedokteran, Universitas Diponegoro, Jln. Prof H. Soedarto, SH Kampus Tembalang Semarang. Kode Pos : \\ 50275. Telp : 024-7460020 \\ ${ }^{3}$ RSUP Dr. Kariadi Semarang, Jalan Doktor Sutomo No.16, Randusari, Semarang Selatan, Kota Semarang, Jawa \\ Tengah 50244, Telepon: (024) 8413476
}

\begin{abstract}
Background : Pulmonary tuberculosis (TB) is a global public health problem including Indonesia. Generally malnourished due to side effect anti-tuberculosis drugs, wich altering gastrointestinal tract, it effects on immune system and response. Probiotics and Selenium are thought to have beneficial effects for the immune system and nutritional status on $T B$ patients

Objective : To analyze the effect of combination probiotic and selenium supplementation on Neutrophill Lymphocyte count Ratio ( NLR ), Hemoglobin and Albumin in Wistar-induced rat by Mycobacterium tuberculosis

Methods : Experimental research with Randomized Post Test Control Group Design. Animals Wistar rats of 28 tails, randomized into 4 groups. The treatment of group 1 : the control of group received standard treatment of OAT, the treatment of group 2 : received a probiotic + OAT, the treatment of group 3 received a selenium + OAT, the treatment of group 4 received a probiotic and selenium + OAT. After 14 days induced, animals were given 28 days treatment according to their group. Data analyzed by Anova, Post Hoc or Kruskal Wallis, Mann Whitney at significance level $p<0.05$.

Results : Decreased levels of NLR, Haemoglobin and Albumin on the treatment group 1 ( $p<0.05)$, the treatment group 2 (p,0.05), the treatment group 3 (p,0,05). The most powerful effectiveness of the combination probiotic and selenium contained in the NLR, Haemoglobin and Albumin

Conclusion : Supplementation of probiotics and selenium given concurrently provides a good effect for increased levels of NLR, haemoglobin and albumin was better than control group.
\end{abstract}

Keywords: Probiotics, Selenium, Neutrophil Lymphocyte count Ratio (NRL), Haemoglobin, Albumin, Mycobacterium Tuberculosis

\section{ABSTRAK}

Latar belakang : Penyakit tuberkulosis (TBC) paru merupakan masalah kesehatan masyarakat global termasuk Indonesia. Penyakit tuberkulosis paru pada umumnya terjadi malnutrisi akibat efek samping obat anti tuberculosis, yang menyebabkan gangguan saluran cerna dan respon imunitas. Probiotik dan Selenium diduga memiliki efek menguntungkan respon imunitas dan status gizi pada pasien terinfeksi tuberculosis

Tujuan : Untuk menganalisis pengaruh pemberian suplementasi probiotik dan selenium terhadap NLR ( Neutrophill Ratio Lymphocyte ), Hemoglobin dan Albumin pada tikus wistar yang diinduksi Mycobacterium tuberculosis.

Metode : Penelitian eksperimen dengan rancangan Randomized Post test Control Group Design. Dua puluh delapan tikus Wistar dibagi 4 kelompok, kelompok 1 : kelompok kontrol hanya diberikan OAT, kelompok 2 : probiotik + OAT, kelompok 3 : selenium + OAT serta kelompok 4 : probiotik dan selenium + OAT. Setelah diinduksi 14 hari, hewan diberikan perlakuan selama 28 hari. Analisis data menggunakan Anova, Post Hoc atau Kruskal Wallis, Mann Whitney pada tingkat kemaknaan $p<0.05$.

Hasil : Terjadi penurunan kadar NLR, peningkatan kadar Hemoglobin dan Albumin pada tikus kelompok 1 (p<0.05), kelompok $2(p<0.05)$ serta kelompok 3 ( $p<0.05)$. Efektifitas pemberian probiotik dan selenium paling kuat terdapat pada NLR, Hemoglobin dan Albumin

Simpulan : Suplementasi probiotik dan selenium selama 28 hari mampu meningkatkan sistem imunitas ( NRL ), Hemoglobin dan Albumin pada kelompok perlakuan lebih baik dibanding kelompok kontrol.

Kata Kunci : Probiotik, Selenium, NRL, Hemoglobin, Albumin, Mycobacterium Tuberculosis

\section{PENDAHULUAN}

Tuberkolosis paru (TBC) merupakan infeksi menular akibat Mycobacterium tuberculosis, penyebab kesakitan, kematian dan masalah kesehatan masyarakat Indonesia. ${ }^{1}$ Badan kesehatan dunia (WHO), menyatakan terdapat kurang lebih 1,4 juta 
orang meninggal setiap tahun dan sebesar $61 \%$ berada di Asia pada tahun 2015. ${ }^{2}$ Indonesia tahun 2014, terdapat jumlah TBC paru kasus baru dengan BTA positif sebanyak 176.677 kasus di seluruh provinsi, sedangkan pasien TBC paru yang harus diobati adalah $65 \%$, baru dilakukan sebesar $49,92 \%$ di Provinsi Jawa Barat. ${ }^{3}$ Hingga kini belum ditemukan panduan pengelolaan gizi bagi penderita yang dalam perawatan, sehingga mengakibatkan TBC menjadi multi drug resistence $12 \% .^{4}$ Pilar pengobatan TBC meliputi penggunaan obat antiotik, diet dan penambahan zat gizi mikro, namun belum mampu memberikan efek yang maksimal.

Determinan penyakit tuberkulosis paru salah satu adalah infeksi dan status gizi. Status gizi buruk meningkatkan risiko penyakit, sebaliknya proses perjalanan penyakit mempengaruhi status gizi dan daya tahan tubuh., ${ }^{5,6}$ Hasil penelitianTB paru ditemukan menderita malnutrisi sebanyak $55,6 \%$ di BKPM Semarang tahun 2014, didapati menderita kekurangan energi kronis, defisiensi mikronutrien seperti defisiensi zinc dan retinol plasma,selenium dan probiotik pada kelompok usia produktif di Indonesia. Infeksi mengakibatkan inflamasi kronis, penurunan asupan, malabsorpsi nutrient, perubahan metabolisme tubuh dan radikal bebas, immunitas tubuh dan antioksidan tubuh menurun. ${ }^{7,8}$ Obat-obat TBC berspektrum antibiotik kuat, menyebabkan kerusakan pada saluran pencernaan pada makroflora usus, penurunan penyerapan zat gizi, menurunnya respon imun tubuh yang disertai dengan penurunan status gizi dan nafsu makan penderita dan penyebab mual, muntah, diare, tidak nafsu makan, peningkatan suhu tubuh dan penurunan makroflora usus. ${ }^{9}$ Pasien tuberculosis paru, mengalami penurunan status gizi disebabkan tingkat perilaku terhadap makanan dan kesehatan, khususnya kecukupan energi dan protein, lama menderita penyakit paru, serta pendapatan perkapita pasien. 5,7,9 Perbaikan gizi upaya untuk memutus lingkaran setan penularan dan pemberantasan tuberculosis.

Kurang gizi, tubuh kekurangan zat gizi makro dan mikro, melalui peningkatan kebutuhan metabolik dan penurunan intake. Kekurangan gizi dapat memperburuk penyakit, atau menunda pemulihan dengan menekan respon imunitas tubuh. Parameter Neutrophill Ratio Lymphocyte (NRL) merupakan biormarker inflamasi sistemik dan stress yang dapat menggantikan C Reactive Protein (CRP) yang mudah dan handal. ${ }^{10-14}$ Kondisi kekurangan energi protein kronis tuberculosis paru mempengaruhi daya tahan tubuh, respon imunitas tubuh terhadap penyakit, penurunan kadar albumin dan haemoglobin darah.

Zat gizi mikro berperan dalam perbaikan penyakit dan imunitas penderita tuberculosis adalah selenium. Selenium bekerja mengaktivasi respon antioksidan endogen, menetralkan radikal bebas melalui donor elektron. Proses inflamasi menginduksi pembentukan ROS yang toksik terhadap bakteri tuberkulosis dan sel normal, reaksi peroksidasi lipid ROS membentuk oksidan Malondialdehit (MDA), zat ini merusak integritas sel dan nucleus berhubungan dengan terjadinya fibrosis paru. Penelitian menunjukkan suplementasi zinc, vitamin A dan prebiotik pada penderita TB paru dapat meningkatkan status gizi, $\mathrm{Hb}$, zinc plasma, retinol plasma, lemak tubuh, peningkatan sistem imun neutropil, sedangkan suplementasi selenium terkait penguatan imun tubuh belum pernah dilakukan.

Sistem pertahanan tubuh manusia terdiri dari sistem pertahanan spesifik dan non-spesifik. Sel utama yang berperan dalam pertahanan non spesifik adalah sel mononuklear ( neutropil, monosit dan makrofag). Mekanisme kerja tubuh yang kompleks sangat tergantung pada makrofag dan pelepasan neutrofil dari berbagai molekul oksidatif untuk menghancurkan mikroba. Neutrofil merupakan sel pertama yang dikerahkan ke tempat bakteri masuk dan berkembang dalam tubuh, sebagian besar komponen leukosit dalam sirkulasi merupakan neutrofil. Sel induk membutuhkan sistem antioksidan yang kuat di mana selenoproteins memainkan peran penting yang utama. Sintesis dari metionin, sistein adalah asam amino dalam molekul glutathione, dan merupakan prekursor untuk peroksidase enzim glutation, kedua bagian dari sistem pertahanan antioksidan. ${ }^{15}$ Penelitian penderita TB di Korea, menunjukkan mikro mineral memiliki kadar zinc $(\mathrm{Zn})$ and selenium $(\mathrm{Se})(\mathrm{p}<0,01)$ dan sedangkan dalam serum $(p<0,5) \cdot{ }^{16-18}$ Penelitian selenium terdahulu dibeberapa penelitian belum memberikan hasil mengembirakan.

Probiotik pontensial merekoveri kerusakan mikroflora usus, respon imun serta mendukung anti inflamasi ( IL10 ). Gabungan probiotik terbukti memperbaiki makroflora usus pada penderita TBC, dapat berpengaruh sebagai imunomodulator dan stimulasi imunoprotektif, serta peningkatan sistem imun dengan mengaktivasi Th2. Probiotik bisa bertindak stimulasi imunoprotektik dengan mengaktivasi Th1. Makrofag dalam sistem imun ikut berperan pada respon Th1 (IFN $\gamma$, TNF $\alpha$, IL2 ) atau Th2 ( IL4, IL5, IL6, IL10, IL13 ) menyebabkan tejadinya respon proinflamasi. Ada dugaan sel makrofag yang terpapar probiotik secara berkesinambungan juga akan mengalami penekanan fungsi, ditandai dengan penurunan produksi sitokin (IL1, IL6) dan peningkatan produksi IL10 meningkat. Peran IL10 menghambat sel Th1. ${ }^{18-20}$

Berdasarkan latar belakang tersebut peneliti mengajukan suplementasi probiotik dan selenium 
mempengaruhi kadar NLR, Albumin dan Hemoglobin pada Hewan Tikus Wistar yang diinduksi kuman Mycobacterium Tuberculosis

\section{METODE}

Penelitian eksperimental dengan Randomized Post test Control Group Design ${ }^{21}$ dengan 28 hewan coba tikus Wistar jantan dengan berat $150-200$ gram sebanyak 28 ekor, diaklimitimasi di laboratorium selama 2 hari. Tujuan aklimitasi guna menyesuaikan lingkungan Laboratorium Parasitologi Fakultas Kedokteran Universitas Diponegoro Semarang. Tikus Wistar diberi pakan standar Tinggi Kalori Tinggi Protein (TKTP) AIN-93. Hewan coba induksi strain bakteri Mycobacterium yang segar diperoleh dari pasien penderita TBC. Setelah proses induksi hewan, selama 14 hari, diamati untuk melihat peroses keberhasilan induksi. Sebanyak 28 ekor tikus, dirandomisasi yang menjadi 4 kelompok yang masing-masing mendapat 7 ekor, yaitu kelompok kontrol menerima pengobatan standar obat TBC. Kelompok perlakuan probiotik ditambahkan pengobatan standar obat TBC. Kelompok perlakuan selenium ditambah pengobatan standar obat TBC. Kelompok perlakuan probiotik, selenium ditambah pengobatan standar obat TBC. Setelah diinduksi 14 hari, hewan diberikan perlakuan sesuai kelompoknya. Pengukuran data akhir (pos test) penelitian terhadap respon imun ratio neutrophil liphocyte [NRL], Haemoglobin, albumin tikus percobaan yang tikus diinfeksi isolate TB. Data dianalisis Anova, Post Hoc atau Kruskal Wallis, Mann Whitney pada tingkat kemaknaan $\mathrm{p}<0,05$. Penelitian telah disetujui Komisi Etik Kesehatan Kedokteran Universitas Diponegoro Semarang.

\section{HASIL}

Hasil penelitian menunjukkan bahwa berat badan hewan coba sebelum perlakuan adalah 110,20 $\pm 11,56$ gram, sedangkan setelah induksi bakteri mikobakterium tuberculosis menjadi 91,15 \pm 9,21 gram.

Tabel 1. Deskripsi Perubahan Berat Hewan Coba Sebelum dan Sesudah Induksi Mikobakterium Tuberculosis

\begin{tabular}{ccccc}
\hline No & Variabel & Awal (gr) & Akhir Induksi (gr) & p-value \\
\hline 1 & Berat Badan (gr) & $110,20 \pm 11,56$ & $91,15 \pm 9,21$ & $0,001^{\mathrm{a}}$ \\
\hline
\end{tabular}

${ }^{\text {a }}$ Pairs t-test, kemaknaan $\mathrm{p}<0,001$

Kadar albumin paling rendah adalah sebesar 2,78 $\pm 0,00 \mathrm{mg} / \mathrm{dl}$ pada kelompok kontrol, perubahan peningkatan sebesar 2,94 $\pm 0,01 \mathrm{mg} / \mathrm{dl}$ kelompok selenium, peningkatan paling besar 3,33 $\pm 0,46 \mathrm{mg} / \mathrm{dl}$ kelompok suplementasi probiotik selenium, kelompok probiotik sebesar 3,00 $\pm 0,05$ $\mathrm{mg} / \mathrm{dl} .(\mathrm{p}<0,040)$.

Kadar Albumin, mg/dl

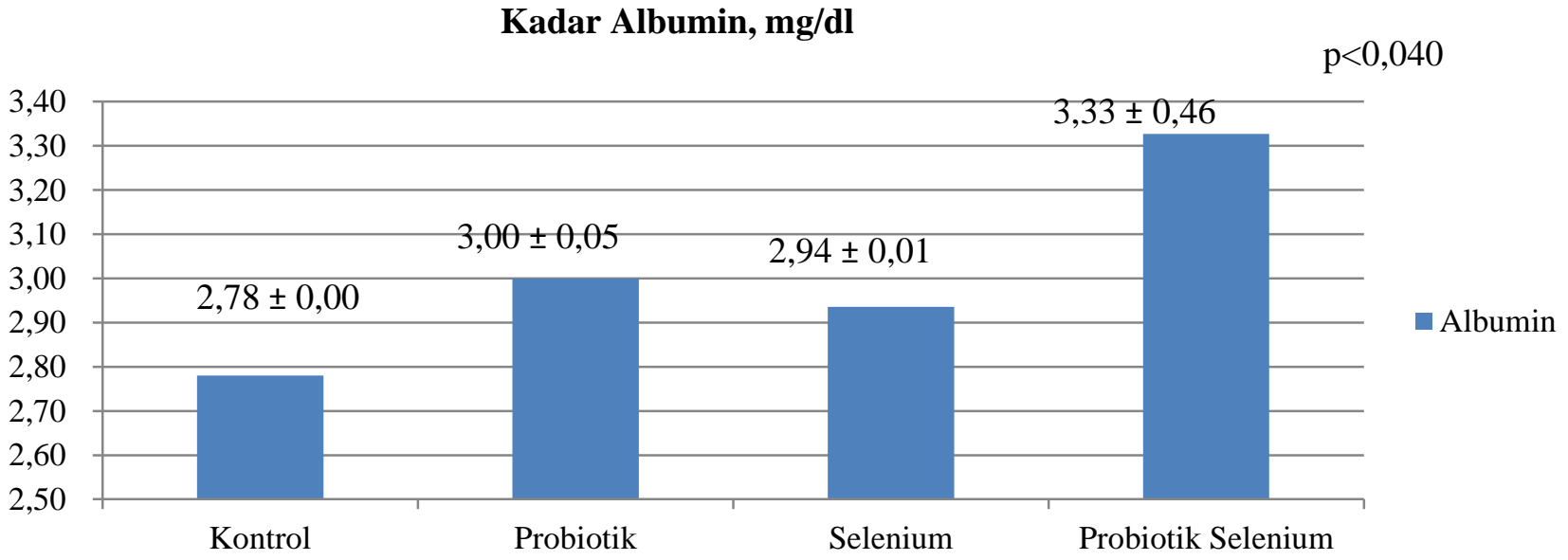

Kruskal Wallis, tingkat kemaknaan $\mathrm{p}<0,05$

\section{Gambar 1. Perbandingan perbedaan kadar albumin antar kelompok hewan coba}

Kadar hemoglobin peningkatan yang paling sebesar 13,7 $\pm 0,21 \mathrm{~g} / \mathrm{dl}$ kelompok selenium, kelompok probiotik sebesar $13,4 \pm 0,16 \mathrm{~g} / \mathrm{dl}$, kelompok probiotik selenium mengalami peningkatan $12,9 \pm 1,95 \mathrm{~g} / \mathrm{dl}$. $(\mathrm{p}<0,028)$. 


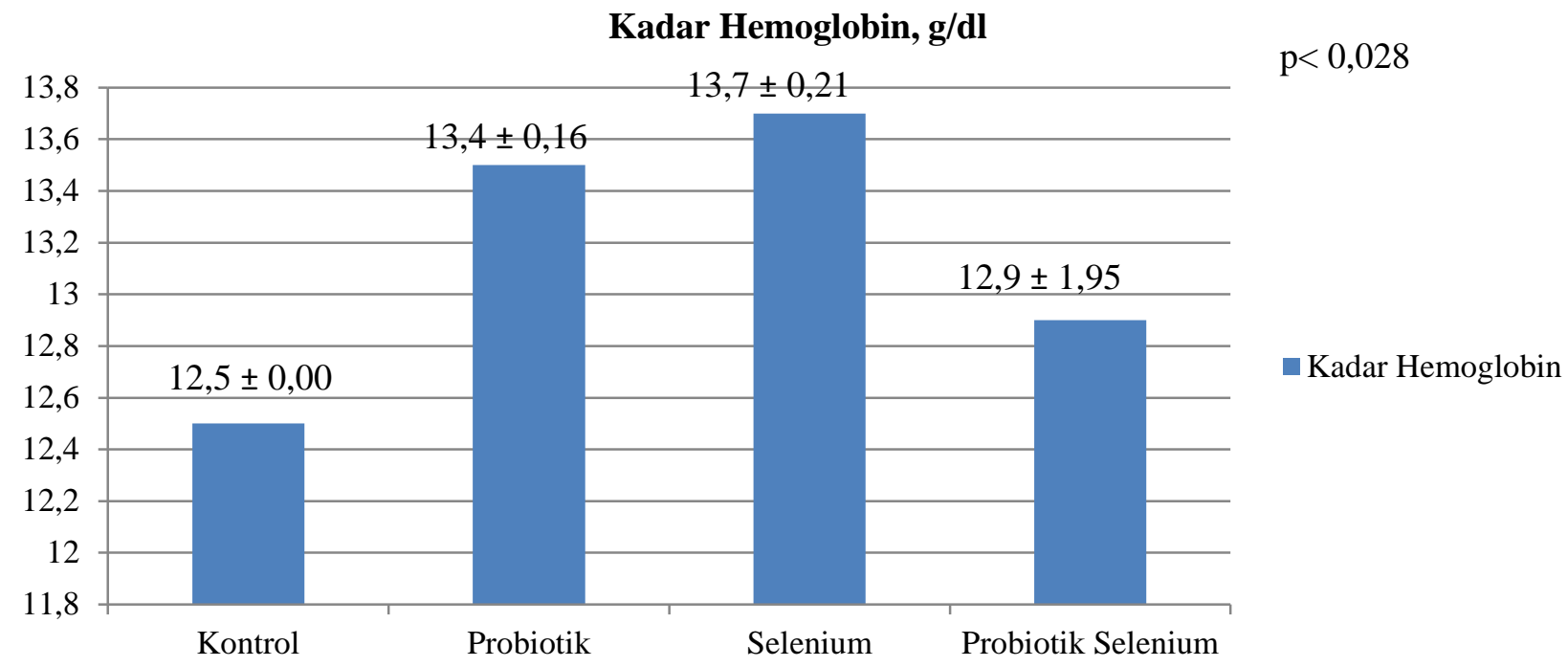

Kruskal Wallis, tingkat kemaknaan $\mathrm{p}<0,05$

Gambar 2. Perbandingan perbedaan kadar hemoglobin antar kelompok hewan coba

Rasio neutrofil limfosit dikedua kelompok perlakuan yaitu kelompok selenium dan probiotik selenium $0,32 \pm 0,05,0,54 \pm 0,267$ pada kelompok selenium, kelompok probiotik selenium 0,32 $\pm 0,05$.
Kelompok probiotik dan kontrol tidak mengalami peningkatan, yakni berada sebesar $0,21 \pm 0,02$ dan $0,45 \pm 0,00 .(p<0,001)$.

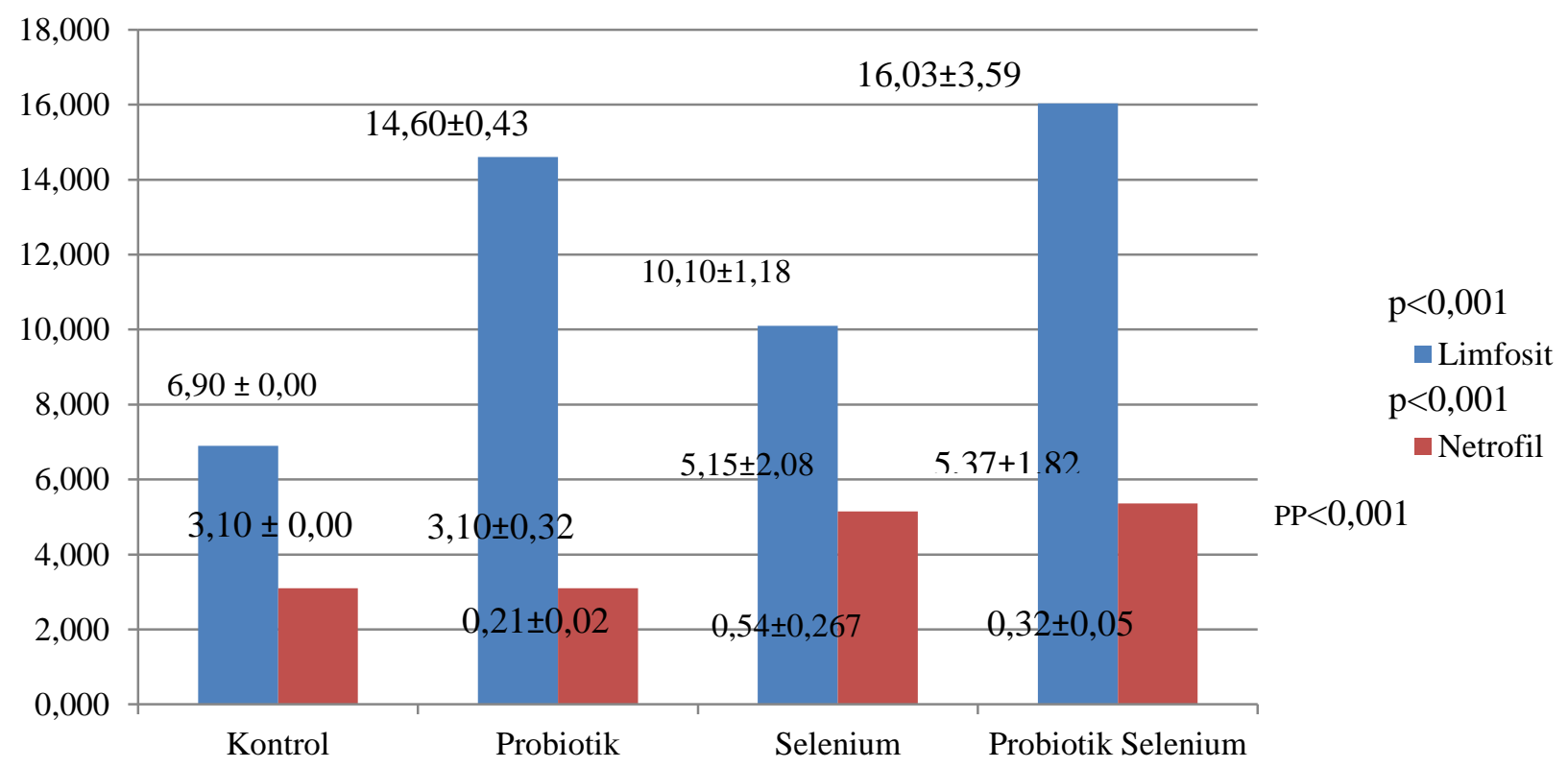

Kruskal Wallis, tingkat kemaknaan $\mathrm{p}<0,005$

Gambar 3. Perbandingan perbedaan kadar limfosit, neutrofil dan rasio nutrofil limfosit antar kelompok hewan coba 


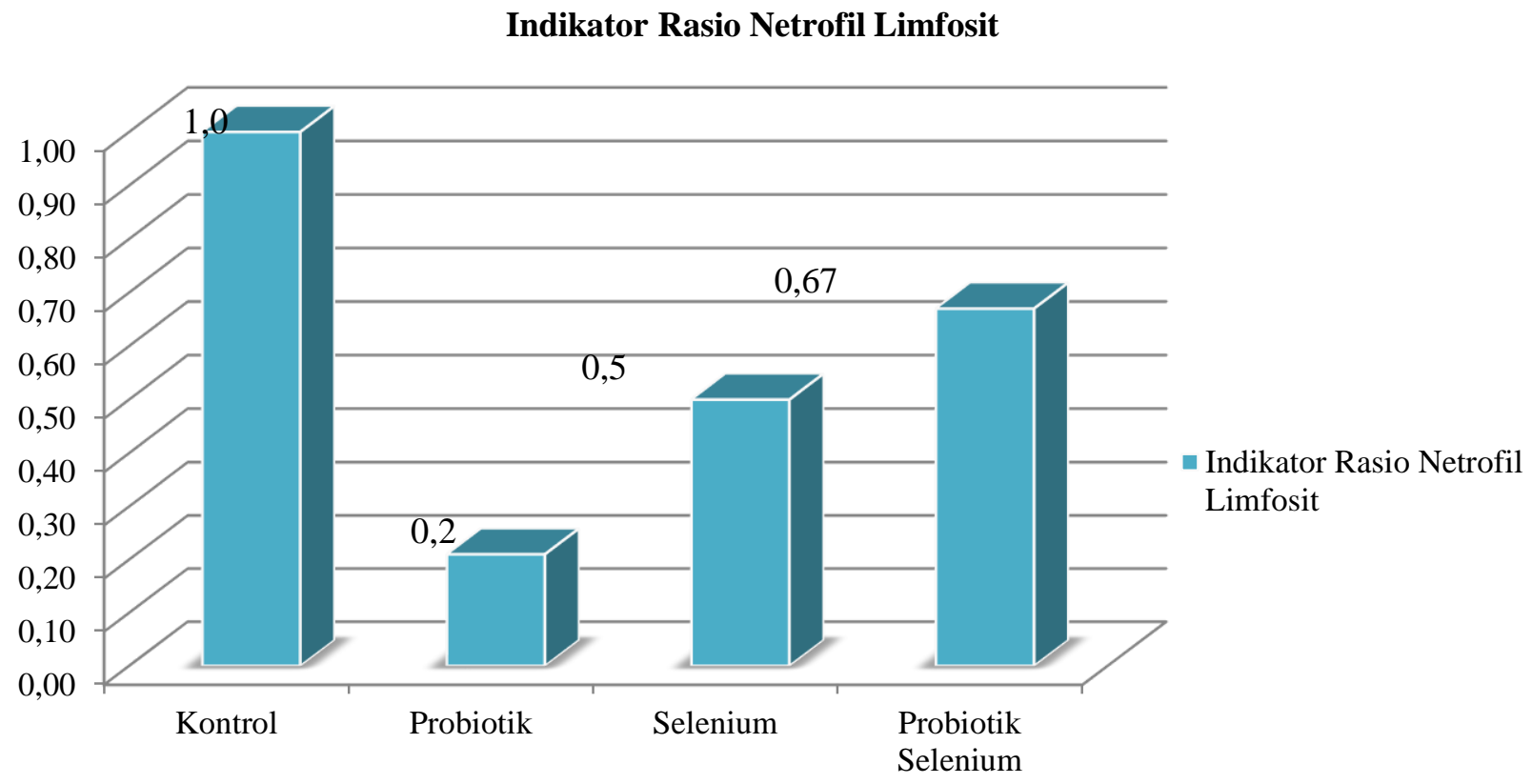

Gambar 4. Indikator Rasio Netrofil Limfosit

Rasio NRL penelitian ini adalah sebagai berikut untuk hewan kelompok kontrol menunjukkan 1,0, kelompok probitik sebesar 0,2, selenium sebesar 0,5 , dan kelompok gabungan probiotik seleniu dipeoleh 0,67 .

\section{Analisa Multivariat}

Berdasarkan uji regresi diperoleh hanya variabel kadar albumin $(0,001)$, limfosit $(0,001)$, neutropil $(0,001)$. Koefisien determinasi (R-Square) 0,989, menjelaskan 98,9\% variasi variabel kadar albumin, neutropil, limfosit dapat menjelaskan dengan jelas terhadap variasi variabel rasio NRL sebesar 98,8\%. ( $\mathrm{p}=0,001)$. Hasil uji multivariat tersebut diperoleh persamaan garis regresi. NRL Hewan TBC $=0,560-0,62[$ Kadar Albumin] $-0,34$ [Kadar Limfosit] - 0,98 [Kadar Netropil]

\section{PEMBAHASAN}

Berdasarkan karakteristik hewan hasil penelitian ini, hewan telah terbukti mengalami kondisi TB setelah diinduksi, hal ini terlihat dari salah satunya perubahan berat badannya. Ada perbedaan berat badan hewan bermakna selama penelitian $(\mathrm{p}<0,001)$. Penurunan berat badan dipengaruhi oleh aktivasi bekerjanya bakteri ditubuh hewan, ditandai menurunnya nafsu makan, status gizi kurang, inflamasi, penurunan berat badan.

Pasien TB mengalami kekurangan energi protein kronis, berakibat penurunan kadar albumin, haemoglobin darah. Kadar albumin merupakan salah satu parameter status gizi, kondisi albumin yang rendah dan buruk akan meningkatkan kejadian infeksi dan risiko penyakit dan kontribusi menyebabkan status gizi buruk, karena proses perjalanan penyakit yang mempengaruhi daya tahan tubuh dan tingkat kesembuhan penderita. Munculnya infeksi pada TB mendorong peningkatkan reaksi inflamasi kronis yang ditandai dengan peningkatan suhu panas tubuh, penurunan asupan, malabsorpsi nutrien serta perubahan metabolisme tubuh. 8 Penggunaan obat-obat TBC berspektrum misalnya antibiotik kuat, menyebabkan kerusakan pada saluran pencernaan. Ditambahkan, penggunaan antibiotika obat anti tuberculosis juga yang menyebabkan mual, muntah, diare, tidak nafsu makan, peningkatan suhu tubuh dan penurunan makroflora usus. Penurunan makroflora usus inilah menyebabkan penurunan penyerapan zat gizi. Penurunan respon imun tubuh, disertai dengan penurunan status gizi dan nafsu makan penderita. Selain inflamasi mengakibatkan radikal bebas, immunitas tubuh dan antioksidan tubah menurun.

Hemoglobin merupakan komponen alat transportasi oksigen $(\mathrm{O} 2)$ dan karbon dioksida $(\mathrm{CO} 2)$ dari sebuah proses metabolisme dalam tubuh secara normal. $\mathrm{Hb}$ tersusun dari globin (empat rantai protein yang terdiri dari dua unit alfa dan dua unit beta) dan heme (mengandung atom besi dan porphyrin: suatu pigmen merah). Pigmen besi hemoglobin bergabung dengan oksigen. Nilai kadar $\mathrm{Hb}$ berbeda secara individual, karena berbagai adaptasi tubuh, secara umum jumlah hemoglobin normalnya adalah 12 $\mathrm{g} / \mathrm{dL}$, dalam kondisi tertentu dapat mengalami penurunan misalnya penyakit paru-paru yang mengakibatkan anemia, akibat efek penyakit dan penggunaan obat berspektrum antibiotik tinggi dapat menyebabkan penurunan $\mathrm{Hb}$. Kondisi anemia inilah dapat memperlambat penyembuhan penyakit TBC. 
Beberapa penelitian menunjukkan pemberian probiotik dapat meningkatkan kualitas hidup dan status kesehatan serta dipergunakan dalam pencegahan, mengobati berbagai penyakit. Probiotik meningkatkan status kesehatan manusia melalui mekanisme kerja probiotik melalui kemampuannya sebagai antioksidan, hipokolesterolemik, antikarsinogenik, antibiotik, immunomodulasi, meningkatkan biometabolisme, mengurangi intoleransi laktosa. Peran peningkatan biometabolisme dapat dilakukan melalui menghasilkan enzim proteolitik di dalam lambung (pepsin, papain) dan usus halus (tripsin, kimotripsin, protease pankreatik) berfungsi untuk digesti. Pemecahan polipeptida menjadi dipeptida dan tripeptida bertujuan agar dapat terjadi proses digesti dan absorpsi bahan makanan, dan membentuk protein imunogenik yang bersifat nonimun (peptida dengan panjang asam amino $<8-10$ bersifat imunogenik yang buruk). Efek protease berlipat ganda dengan adanya garam empedu yang memecah karbohidrat dan protein, sehingga melalui aktivitas biometabolisme ini tubuh akan dapat memenuhi kebutuhan asupan gizi yang dapat meningkatkan status gizi.

Penelitian Lesley J. B, et al 1996 menemukan aktivitas Adenosine Deaminase (ADA) pada efusi tuberkulosis secara signifikan lebih tinggi daripada kelompok diagnostik lainnya $(\mathrm{p}<0,005)$. Tambahan rasio neutrofil limfosit 0,75 atau lebih tinggi dimasukkan, sensitivitas, spesifisitas untuk identifikasi TB.

Beberapa penelitian terkait pemanfaatan NRL sebagai indikator inflamasi yang dibedakan tergantung jenis penyakit. Amanda Shreders, 2016 menyatakan penggunaan cut off point NRL menjadi 2 , yaitu NRL $\geq 3$ yang menyatakan keadaan yang sangat kuat terhadap terjadinya inflamasi pada deteksi penyakit akut dan kronis gangguan gondok, sebaliknya NRL <3, tidak tidak memberikan efek terhadap peningkatan inflamasi. Berdasarkan hasil penelitian dapat dikatakan intervensi pemberian probiotik, selenium dan gabungan probiotik selenium menunjukan hasil masih dibawah standar atau dealam pengertian baik atau peningkatan inflamasi dapat dikendalikan dengan baik, karena NRL masih dibawah cut off point 0,75 (standar). Neul-Bom, et al 2013, menunjukkan NLR adalah penanda laboratorium yang berguna untuk membedakan antara pasien dengan TB paru dan Bacterial Community-Acquired Pneumonia (CAP) bakteri lainnya pada tahap diagnostik awal untuk prevalensi TB. NLR $<7$ adalah nilai cut-off yang optimal untuk membedakan pasien dengan TB paru dari pasien dengan CAP bakteri; 3) Kemampuan diagnostik NLR lebih tinggi dari pada CRP, hitung sel darah merah, jumlah neutrofil, dan jumlah limfosit untuk membedakan pasien dengan TB paru dari pasien dengan CAP bakteri. Ini adalah studi pertama yang menunjukkan kemampuan diagnostik NLR untuk membedakan antara TB paru dan CAP bakteri.

Respon kekebalan fisiologis dari leukosit yang beredar terhadap berbagai kejadian stres ditandai dengan peningkatan jumlah neutrofil dan penurunan jumlah limfosit. Peningkatan total sel darah merah dan neutrofil adalah reaksi inflamasi, terutama bila disebabkan oleh infeksi bakteri. Limfositosis juga telah digambarkan sebagai penanda diagnostik infeksi bakteri. Oleh karena itu, NLR dianggap memiliki kekuatan diskriminatif yang lebih kuat untuk memprediksi bakteriemia dibandingkan dengan disolusi berdasarkan neutrofilia atau limfositopenia saja. Goodman dkk, awalnya menyarankan kegunaan NLR untuk mendiagnosis pasien dengan dugaan radang usus buntu. Penelitiannya NLR adalah parameter yang lebih sensitif terhadap infeksi bakteri daripada jumlah sel darah merah yang meningkat. Zahorec dkk menemukan sebuah studi observasi longitudinal prospektif, di mana mereka melaporkan adanya korelasi antara tingkat keparahan klinis dan limfositopenia pada pasien dengan sepsis berat dan syok septik pada unit perawatan intensif onkologis. Mereka mengusulkan penggunaan NLR sebagai penanda infeksi tambahan di unit perawatan intensif. Baru-baru ini, de Jager dkk menunjukkan bahwa baik limfositopenia dan NLR adalah prediktor bakteremia yang lebih baik daripada parameter rutin seperti tingkat CRP, jumlah sel darah merah, dan jumlah neutrofil di unit perawatan darurat. Saat ini, NLR telah mengumpulkan minat sebagai prediktor bertahan hidup dalam berbagai situasi klinis, mulai dari onkologi hingga penyakit diovaskular.

Berdasarkan hasil analisis multivariat dapat dijelaskan sebagai berikut. Menurut Corthesy,2007, mengemukan bahwa mekanisme kerja probiotik didalam saluran pencernaan. Bagan ini menjelaskan berbagai konsekwensi dari cross-talk antara bakteri probiotik dan mukosa usus. Pada tingkat epitel usus, bakteri probiotik melakukan yaitu kolonisasi sementara dan pelepasan senyawa bioaktif. Terjadi penguatan secara langsung fungsi sel epitel usus, memodulasi dan melepaskan sitokin dan kemokin. Meskipun terbatas, translokasi bakteri ke lamina propria berpengaruh pada imunitas bawaan dan adaptif dengan mengaktifkan produksi sitokin oleh monosit / makrofag. Sampling oleh sel M di patch Peyer's (PP) dan terperangkap oleh sel dendritik (DC), menyajikan antigen mikroba pada naive sel $\mathrm{T}$ dalam PP dan kelenjar getah bening mesenterika (mesenteric lymph nodes (MLN). Hal ini menyebabkan respon IgA mucosa antibody-mediated terjadi untuk mencegah pertumbuhan berlebih dan 
penyebaran terhadap bakteri, misalnya, terhadap antigen yang dikodekan oleh strain probiotik rekombinan digunakan sebagai vaksin. Jalur pemrosesan yang sama berperan penting dalam pembentukan sistem kekebalan mukosa kearah noninflamasi, pola tolerogenik melalui induksi sel T regulator. Sistem imun usus baik, maka akan mempengaruhi keseluruhan imun tubuh.

Selenium merupakan bagian penting dari enzim antioksidan melindungi sel tubuh, terhadap efek negatif oleh radikal bebas. Selenium (Se) adalah suatu zat gizi mikro (trace element) yang sangat esensial pada sejumlah protein yang berkaitan dengan fungsi enzim, termasuk glutation peroksidase, glutation reduktase, dan tioredoksin reduktase. Selenoprotein (ikatan rantai sedang protein) dipercaya memainkan peran penting sebagai enzim antioksidan (selenosistein). ${ }^{34}$ Selenium bekerja sebagai kofaktor untuk enzim yang terlibat dalam oksidasi asam lemak dan penyerapan asam amino. Tugas utamanya dalam perlindungan membran sel dan sintesis suatu enzim antioksidan glutathione peroxidase yang berfungsi sebagai antioksidan pertahanan tubuh dari pengurangan hidrogen peroksida. Selenium membantu memelihara elastisitas jaringan. Selenium membantu melindungi membran sel, memastikan kebutuhan sel terhadap oksigen tercukupi, membantu pertumbuhan normal dan menjaga kesuburan, melindungi dari pengaruh berbahaya seperti logam berat misalnya raksa, dan memperlancar proses produksi prostaglandins. Melaui proteksi terhadap keutuhan sel maka tubuh dalam melangsungkan fungsi yang normal.

Selenium juga berperan pada sistem imunitas dan fungsi kelenjar tiroid yang baik. Kondisi kelenjar tiroid yang normal, dapat memberikan efek metabolisme dalam tubuh dapat berfungsi normal.

Berdasarkan penelitin ini dapat dibuktikan hipotesa bahwa suplementasi probiotik dan selenium meningkatkan respon imun rasio NRL menunjukan peningkatan yang paling tingi. Pemberian perlakuan ada perubahan peningkatan rasio NRL terhadap tubercolosis lebih baik dibanding kelompok kontrol Hewan Tikus Wistar yang diinduksi kuman Mycobacterium tuberculosis suplementasi probiotik dan seleneum.

Koefisien determinasi (R-Square) 0,989, bahwa model regresi ini yang diperoleh dapat menjelaskan 98,9\% variasi variable dependen NRL. Variable kadar albumin, neutropil, limfosit dapat menjelaskan dengan jelas terhadap variasi variabel rasio NRL sebesar 98,8\%. Hasil ini menujukkan bahwa koefisien determinasi diperoleh sangat baik (kuat) dengan kata lain dikatakan baik bila R-Square lebih dari minimal 60\%. Hasil uji Anova terlihat uji F dengan nilai $\mathrm{p}=0,001$, berarti pada $\alpha=5 \%$ dapat dinyatakan bahwa model regresi cocok (fit) dengan data yang ada, artinya ketiga variable tersebut secara bermakna (significant), sehingga dengan demikian dapat memprediksi NRL. Hasil uji multivariat tersebut diperoleh persamaan garis regresi :

NRL Hewan TBC = 0,560 - 0,62[Kadar Albumin] - 0,34 [Kadar Limfosit] - 0,98 [Kadar Netropil]

Rasio NRL hewan coba diinduksi TBC akan mengalami penurunan sebesar 0,560 dan 1,94 bila mempunyai riwayat kadar albumin, limfosit dan netropil yang mengalami penurunan (rendah). Nilai Beta menunjukkan variable paling berperan, semakin besar nilai Beta semakin besar pengaruhnya terhadap variable dependen (NRL). Hasil diatas berarti variable kadar neutropil (koefisen Beta $=0,992$ ) menunjukan hasil yang paling besar pengaruhnya terhadap penentuan NRL Hewan coba diinduksi TBC.

\section{SIMPULAN}

Suplementasi probiotik selenium meningkatkan kadar albumin, hemoglobin, respon imun rasio NRL. Peningkatan rasio NRL terhadap tubercolosis lebih baik dibanding kelompok kontrol. NRL Hewan TBC $=0,560-0,62$ [Kadar Albumin] 0,34 [Kadar Limfosit] - 0,98 [Kadar Netropil]. Suplementasi probiotik dan selenium yang diberikan bersamaan memberikan efek yang baik bagi peningkatan kadar albumin, hemoglobin, respon imun penederita $\mathrm{TB}$.

\section{SARAN}

Perlu dilanjutkan penelitian mempergunakan sampel pasien TB variabel penelitian yang lebih lengkap dan kompleks terkait untuk melihat perubahan keberhasilan pengobatan.

\section{DAFTAR PUSTAKA}

1. Kementerian Kesehatan Republik Indonesia 2015. Profil Kesehatan Indonesia Tahun 2014.Jakarta : Kementerian Kesehatan RI. 2015

2. WHO, 2016. Global Tuberculosis Report 2016.http://www.who.int/tb/ publications/global_report/gtbr2016_executive_ summary. pdf?ua $=1$

3. Dinas Kesehatan Propinsi Jawa Barat, 2014. Profil Kesehatan Jawa Barat 2014.

4. L Grobler, Nagpal S, Sudarsanam TD, Sinclair DNutritional supplements for people being treated for active tuberculosis.Cochrane Database Syst Rev. 2016 Jun 29;(6):CD006086. doi: 10.1002/14651858.CD006086.pub4

5. Katleen Mahan, Sylvia Escott Stump. 2004. Krause's Food, Nutrition and Diet Therapy. 11 Edition. Saunders. Philadelphia, Pennsylania 19106. Hal 956-957,1037 
6. Abul K.Abbas, Andrew H. Lichtman, Shiv Pillai. 2010. Celullar and Molecular Immunology, Updated Edition, Edition 6. Saunders Elsivier

7. Zulia Setyaningrum, 2016. Effect of Combined Probiotics and Zinc Supplementation Immune Status of Pulnary Tuberculosis Patients. Pakistan Journal of Nutrition 15 (x):xx-xx

8. Holil M. Par'i. 2016. Pemantauan Status Gizi. Jakarta : EGC

9. Suparman, Hardinsyah, Clara M Kusharto, Ahmad Sulaeman; Dan Bachti Alisjahbana Ahmad Sulaeman; dan Bachti Alisjahbana. Efek Pemberian Suplemen Sinbiotik Dan Zat Gizi Mikro (Vitamin A Dan Zinc) Terhadap Status Gizi Penderita Tbc Paru Orang Dewasa Yang Mengalami Kekurangan Energi Kronik) Gizi Indon 2011, 34(1):32-42

10. Um Soo-Jum, Jung-Hun Huh, Ik Soo Chol, DooKeol Lee, Neul-Bom Yoon, Choonhee Son. 2012. Role of The Neutrophil-Lyphocyte Count Ratio in The Differential Diagnosis of Pulmonary Tuberculosis and Bacterial Community Acquired Pnemmonia. C16 Immunodiagnostics For Latent Tuberculosis Infection and Tuberculosis. Thematic poster Sesion. Tuesday, May 22, 2012.

11. Yoon Neu-Bom, Choonhee Son, Soo-Jung Um. 2013. Role of the Neutrophil-Lymphocyte Count Ratio in the Differential Diagnosis between Pulmonry Tuberculosis and Bacterial Community-Acquired Pnemumonia. Annq Lab Med 2013, 33 : 105 - 110.

12. Illiaz Sinem, Raim Iliaz, Gonenc Ortakoylu, Ayse Bahadir, Belma Akbaba Bagci, Emel Caglar. 2014. Value of Neutrophil/lymphocyte ratio in the differential diagnosis ar sarcoidosis and tuberculosis. Annals of Thoracis Medicine: Vol 9, Issue 4, October-December 2014.

13. Lee Seung Jun, Hyang Rae Lee, Tae Won Lee, Sunmi Ju, Sujin Lim, Se-Il Go, Jung-Wan You. 2016. Usefulness of neutrophil to lymphocyte ratio patients with chronic obstructive pulmonary disease : a prospective obeservational study. Korean Journal Intern Med 2016: 891-898

14. Furutate Ryuko, Takeo Ishii, Takashi Montegi, Kumiko Hattori, Yuji Kusunoki, Akihito Gemma, Kozui Kida. 2015. The Neutrophil to Lymphocyte Ratio is Related to Diseas Severity and Exacerbation in Patients with Chronic Obstructive Pulmonary Disease. Internal Medicine 55: 223-229.

15. F.K.Erick, Maleta, E. Govasmark, A. K. Duttaroy, A. G. Bjune. 2009. Food intake of elenium and sulphur amino acids in tuberculosis patients and healthy adults in Malawi. Int $\mathbf{J}$ Tuberc Lung Dis 13(10):1313-1315

16. SI Farah, Abdelrahman AA, North EJ, Chauhan H. 2016 Opportunities and Challenges for Natural Products as Novel Antituberculosis Agents. Assay Drug Dev Technol. 2016 JanFeb;14(1):29-38. doi: 10.1089/adt.2015.673. Epub 2015 Nov 13.

17. NN Dugina, Chebotareva TV, Mitrokhin SD. 2004. Large intestine dysbacteriosis and therapy efficacy in patients with respiratory tract tuberculosis in sanatoria. Antibiot Khimioter. 2004;49(4):35-8.

18. Choi Rihwa, Hyoung-Tae Kim ,: , Yaeji Lim , Min-Ji Kim, O Jung Kwon, Kyeongman Jeon, Hye Yun Park , Byeong-Ho Jeong , Won-Jung Koh , and Soo-Youn Lee, .Serum Concentrations of Trace Elements in Patients with Tuberculosis and Its Association with Treatment Outcome. Nutrients 2015, 7, 5969-5981; doi:10.3390/nu7075263 OPEN ACCESS nutrients ISSN 2072-6643

19. Surono-Inggrid. Probiotik Susu fermentasi dan Kesehatan.YAPMMI. Hal. 1-70.

20. Judiono, RRJ Djokomoeljanto, Soeharyo Hadisaputro. Biomulcular Aspects of Plain Kefir Antidiabetic Potentials. IJPNH Vol 5 No. 1 / 2, 2012

21. Donald T Campbell, Julian C. Stanley. Experimental and Quasi-experimental designs for research. Rand Mc Nally College Publishing Company, Chicago. 1963. Page 145 - 170.

22. Leslie Gross Portney, Mary P.W. Foundations of Clinical Research Application to Practice. ConnectCut : Apletion \& Lange1993.. p.148 152

23. NS Scrimshaw. 2003. Historical concepts ofinteractions, synergism and antagonis between nutrition and infection. J Nutr133: 316S-321S.

24. ES Wintergerst, Maggini S, Hornig DH. Contribution of selected vitamins and trace elements to immune function. Ann Nutr Metab. 2007;51(4):301-23. Epub 2007 Aug 28.

25. Karnen Garna Baratawidjaja. 2006. Imunologi Dasar Edisi Ke 7. Penerbit Fakultas kedokteran Universitas Indonesia.

26. Kementrian Kesehatan RI. Dirjen Pengendalian Penyakit dan Penyehatan Lingkungan. Pedoman Nasional Pengendalian Tuberkulosis. Jakarta: 2014

27. Kumalaningsih,Sri. Antioksidan alami, Penangkal radikal bebas, cetakan 2. Jakarta : Penerbit Trubus Agrisarana. 2007. Hal. 8-11

28. FAO. Guideline for the evaluastion of probiotic. Report of a Joint FAO/WHO Working Group on 
Drafting Guidelines for the evaluation of Probiotics in Food. 2002. Page 1- 12.

29. Amy C Brown, Ana Valiere. Probiotics and Medical Nutrition Therapy, Nutr Clin Care. 2004 ; 7(2): 56-68

30. Inggrid Surono. Probiotik Susu fermentasi dan Kesehatan.YAPMMI. Hal. 1-70.

31. W.F. Sybesma, Hugenholtz. Food fermentation by lactic acid bacteria for prevention of cardiovasCular. Functional foods, cardiovasCular disease and diabetes. England : Woodhead Publishing Limited, 2004 : page : 448 $-469$

32. Y.M.Khazrai, S Manfrini and P. Pozzilli. Diet and diabetes : prevention and control. Functional foods, cardiovasCular disease and diabetes. England : Woodhead Publishing Limited, 2004 : page : $126-140$

33. S.M Virtanen, Nutritional risk factors in the development of type 1 and type 2 diabetes. Functional foods, cardiovasCular disease and diabetes. England : Woodhead Publishing Limited, 2004 : page : $142-148$

34. Lanny Listiani. 2005. Probiotics in Health system. Makalah Seminar Peran Probiotik dalam menjamin pertumbuhan \& perkembangan anak. Jakarta : 7 Juni, 2005

35. Blaise Corthesy, Gaskins, H Rex; Mercenier, Annick. Cross-Talk Between Probiotic Bacteria and the Host Immune System. Journal of Nutrition, 2007. 137: 781S-790S

36. Zimmerman MT, Bayse CA, Ramoutar RR, Brumaghim JL. Sulfur and selenium antioxidants: challenging radical scavenging mechanisms and developing structure-activity relationships based on metal binding. J Inorg Biochem. 2015 Apr;145:30-40. doi: 10.1016/j.jinorgbio.2014.12.020. Epub 2014 Dec 29

37. MA Beck. 2001. Antioxidants and viralinfections: host immune response andviral pathogenicity. J Am Coll Nutr 20:384S-388S.

38. Lesley J. Burgess, MB, BCha, Frans J. Maritz, MMEDb, Irene Le Rouxc, J.J. Frans Taljaard, Mda. Clinical Investigations: Tuberculosis Combined Use of Pleural Adenosine Deaminase With Lymphocyte/Neutrophil Ratio : Increased Specificity for the Diagnosis of Tuberculous Pleuritis. Chest Volume 109, Issue 2, February 1996, Pages 414-419

39. Neul-Bom Yoon, M.D., Choonhee Son, Ph.D., and Soo-Jung Um, M.D. Role of the NeutrophilLymphocyte Count Ratio in the Differential Diagnosis between Pulmonary Tuberculosis and Bacterial Community-Acquired Pneumonia. Ann Lab Med 2013; 33:105-110
40. Ugajin M, Miwa S, Shirai M, Ohba H, Eifuku T, Nakamura $\mathrm{H}$, et al. Use- fulness of serum procalcitonin level in pulmonary tuberculosis. Eur Respir J 2011;37:371-5.

41. Kang YA, Kwon SY, Yoon HI, Lee JH, Lee CT. Role of C-reactive protein and procalcitonin in differentiation of tuberculosis from bacterial com- munity acquired pneumonia. Korean J Intern Med 2009;24:337-42.

42. Tintinger GR, van der Merwe JJ, Fickl H, Rheeder P, Feldman C, An- derson R. Soluble triggering receptor expressed on myeloid cells in sputum of patients with community-acquired pneumonia or pulmonary tuberculosis: a pilot study. Eur $\mathbf{J}$ Clin Microbiol Infect Dis 2012;31:73-6.

43. Wyllie DH, Bowler IC, Peto TE. Relation between lymphopenia and bac- teraemia in UK adults with medical emergencies. J Clin Pathol 2004; 57:950-5.

44. de Jager CP, van Wijk PT, Mathoera RB, de Jongh-Leuvenink J, van d5er Poll T, Wever PC. Lymphocytopenia and neutrophil-lymphocyte count ratio predict bacteremia better than conventional infection markers in an emergency care unit. Crit Care 2010;14:R192.

45. Zahorec R. Ratio of neutrophil to lymphocyte counts--rapid and simple parameter of systemic inflammation and stress in critically ill. Bratisl Lek Listy 2001;102:5-14.

46. Goodman DA, Goodman CB, Monk JS. Use of the neutrophil: lympho- cyte ratio in the diagnosis of appendicitis. Am Surg 1995;61:257-9.

47. Gibson PH, Croal BL, Cuthbertson BH, Small GR, Ifezulike Al, Gibson G, et al. Preoperative neutrophil-lymphocyte ratio and outcome from coro- nary artery bypass grafting. Am Heart $\mathrm{J}$ 2007;154:995-1002.

48. Halazun KJ, Aldoori A, Malik HZ, Al-Mukhtar A, Prasad KR, Toogood GJ, et al. Elevated preoperative neutrophil to lymphocyte ratio predicts survival following hepatic resection for colorectal liver metastases. Eur J Surg Oncol 2008;34:55-60.

49. Amanda Shreders, Jennifer Arthurs, Nicole Gannon, Deborah Fischer, Laura Finn, James Foran, Vivek Roy. Elevated Neutrophil to Lymphocyte Ratio following Transplant Predicts Future Occurrence of Acute and Chronic Graft-Versus-Host-Disease. Abstracts / Biol Blood Marrow Transplant 22 (2016) S19eS481

50. Adrian R. Martineau, Sandra M. Newton, Katalin A. Wilkinson. Neutrophil-mediated innate immune resistance to mycobacteria. The 
Journal of Clinical Investigation :volume 117, No. 7, July 2007

51. Kwang-Sook Woo, Byoung-Gwon Kim, JaeLim Choi, Bo-Ram Kim, Kyeong-Hee Kim. Neutrophil-to-Limphocyte Ratio Is Associated with Impaired Interferon-Gamma Release to Phytoghaemagglutinin. Plos One. 0125794, May $11,2015$.

52. Qitian He, Wenjun Tang, Yan Deng, Yu He, Li Xie, Xue Qin, Shan Li. The diagnostic value of neutrophil-to-lymphocyte ratio and platelet-tolymphocyte ratio in tuberculous spondylitis. Int J Clin Exp Med 2016;9(8):16360-16366

53. Zhi-Liang Huang, MD, Jun Luo, MD, Min-Shan Chen, MD, Jin-Qing Li, MD, and Ming Shi, MD. Blood Neutrophil-to-lymphocyte Ratio Predicts Survival in Patients with Unresectable Hepatocellular Carcinoma Undergoing Transarterial Chemoembolization. J Vasc Interv Radiol 2011; 22:702-709

54. Kementrian Kesehatan RI. Dirjen Pengendalian Penyakit dan Penyehatan Lingkungan. Pedoman Nasional Pengendalian Tuberkulosis. Jakarta: 2014

55. J.G LeBlanc, , C. Matar, J.C Valdez, G Perdigon. Immonumodulating effects of peptidic fractions issued from milk fermented with Lactobacillus helventicus. Journal of Dairy Science 85, 2002. Page 2733-2742.

56. Rihwa Choi, Hyoung-Tae Kim , Yaeji Lim , Min-Ji Kim, O Jung Kwon , Kyeongman Jeon, Hye Yun Park , Byeong-Ho Jeong , Won-Jung Koh , and Soo-Youn Lee, .Serum Concentrations of Trace Elements in Patients with Tuberculosis and Its Association with Treatment Outcome. Nutrients 2015, 7, 5969-5981; doi:10.3390/nu7075263 OPEN ACCESS nutrients ISSN 2072-6643

57. Jabu T. Mabunda, Lunic B. Khoza, Hubertus B. Van den Borne, Rachel T. Lebese. Needs assessment for adapting TB directly observed treatment intervention programme in Limpopo Province, South Africa: A community-based participatory research approach. African Journal of Primary Health Care \& Family Medicine ISSN: (Online) 2071-2936, (Print) 2071-2928

58. Geneé S Smith, , Stephen K. Van Den Eeden, Cynthia Garcia,Jun Shan, Roger Baxter, Amy H. Herring, David B. Richardson, Air Pollution and Pulmonary Tuberculosis: A NestedCase-Control Study among Members of a NorthernCalifornia Health Plan. EnvironmentalHealthPerspectives. http://dx.doi.org/10.1289/ehp.1408166.

Advance Publication: 9 February 2016

59. E Mortaz, Adcock IM, Ricciardolo FLM,Varahram M, Jamaati H, Velayati AA, et al. (2015). Anti-Inflammatory Effects of LactobacillusRahmnosus and Bifidobacterium Breve onCigarette Smoke Activated Human Macrophages. PLoS ONE10(8): e0136455. doi:10.1371/journal.pone.0136455

60. Renu Gupta., Bandana Thakur, Pushpendra Singh, H.B. Singh, V.D. Sharma, S.V.S. Chauhan. Anti-tuberculosis activity of selected medicinal plants against multidrugresistant Mycobacteriumtuberculosisisolates. Indian $\mathbf{J}$ Med Res 131, June 2010, pp 809-813

61. Joseph Mwanzia Nguta, Regina Appiah-Opong, Alexander K. Nyarko,Dorothy Yeboah-Manu, Phyllis G.A. Addo. Current perspectives in drug discovery againsttuberculosis from natural products. journal homepage: www.elsevier.com/locate/IJMYCO

62. Holger Steinbrenner, Saleh AlQuraishy,Mohamed A Dkhil,Frank Wunderlich,Helmut Sies. Dietary Selenium in Adjuvant Therapy of Viraland Bacterial Infections. American Society for Nutrition. Adv. Nutr. $\quad 6: \quad 73-82, \quad$ 2015; doi:10.3945/an.114.007575

63. Jaquess Percy A, M.S., David L Smalley, Ph.D., And John K. Duckworth, M.D. Enhanced Growth of Mycobacterium tuberculosis in thePresence of SeleniumJournal American Society of Clinical Pathologists00029173/81/0200/0209

64. Berihun Dargie,.,Gezahegn Tesfaye, Amare Worku. Prevalence and associated factors ofundernutrition among adult tuberculosispatients in some selected public healthfacilities of Addis Ababa, Ethiopia: a crosssectionalStudy. BMC Nutrition (2016) 2:7DOI 10.1186/s40795-016-0046-x

65. Yunita Eka Wati, Nunuk Sri Muktiati, Triwahju Astuti. Studi Stres Oksidatif: Kadar Malondialdehyde dan AktivitasSuperoksida Dismutase Plasma pada Tuberkulosis Paru LesiMinimal dan Lesi Luas. J Respir Indo Vol. 33, No. 3, Juli 2013

66. Jia Yu Chi. 2015. Advances in animal models of wound tuberculosis Cina Journal of Burns, 2015,31 (06) : 436-438 DOI : $\quad 10,3760 \quad / \quad$ cma.j.issn.10092587.2015.06.012

67. MD Cohen. 2007. Bacterial host resistance models in the evaluation of immunotoxicity. Methods. 2007 Jan;41(1):20-30.

45. MA Beck, Levande OA, and Handy J. 2003.Selenium deficiency and viralinfection. $J$ Nutr 133: 1463S-1467S.

46. MM Berger, Spertini F, Shenkin A, WardleC, Wiesner L, Schindler C, andChiolerp L. 1998. 
Trace elementsupplementation modulates pulmonaryinfection rates after major burns: adoubble-blind, placebo-controlled trial.Am $J$ Clin Nutr 68: 365-371.

47. $\mathrm{Cu} \mathrm{D}$, Moldoveanu $\mathrm{Z}$, and Stepehensen CB.2000. High level dietary vitamin Aenhances T-helper type 2 cytokineproduction and secretory immunoglobulinA response to influenza A virusinfection in BALB/c mice. $J$ Nutr 130:1132-1139.

48. Villamor E and Fawzy WW. 2005. Effects ofvitamin A supplementation on immuneresponses and correlation with clinicaloutcomes. Clin Microbiol Rev 18: 446464.

49. PG Reeves, Nielsen PH, Fahey GC Jr. 1993. AIN 93 Purified diets for laboratory rodents: Final report of the American Institute of Nutrition ad hoc writing commitee on teh reformulation of the AIN 93 rodent diet. Journal Nutrition 1993 Nov;123(11) : 1939-51
50. D.R.Laurence, A.L Bacharach. 1964. Evaluation of drug activities: Pharmacometrics. Vols 1 and 2. Academic Press Inc Ltd., Barkeley Square House, Barkeley Sq., London W.1 England. Hal 897

51. Amaylia.Oehadian, Hendarsyah Suryadinata, Sumartini Dewi, Riardi Pramudyo, Bachti Alisjahbana. 2013. The Role of Neutrophyl Lymphocyte Count Ratio as an Inflammatory Marker in Systemic Lupus Erythematosus. Acta Medica Indonesiana - The Indonesian Journal of Internal MedicineVol $45 \cdot$ Numb e r 3 • Jul y 2013

52. Adi,Nugroho, Suwarman, A. Muthalib Nawawi. 2013. Hubungan antara Rasio NeutrofilLimfosit dan Skor Sequencial OrFailure Assesment pada Pasien yang Dirawdi Ruang Intensive Care Unit. [Jurnal Anestesi PerioperJAP. 2013;1(3):189-96] 